\title{
Trans-frontier Environmental Damage in International Jurisprudence
}

\author{
Sayyed Ghasem Zamani $^{1} \&$ Mohammadreza Alipour $^{2}$ \\ ${ }^{1}$ Department of Public and International aw, Faculty of Law and Politics, Science and Research Branch, Islamic \\ Azad University, Tehran, Iran \\ ${ }^{2}$ Faculty of Law and Politics, Science and Research Branch, Islamic Azad University, Tehran, Iran \\ Correspondence: Sayyed Ghasem Zamani, Department of Public and International aw, Faculty of Law and \\ Politics, Science and Research Branch, Islamic Azad University, Tehran, Iran. E-mail: drghzamani@gmail.com; \\ mra_alipour@yahoo.com
}

Received: April 27, 2016 Accepted: May 15, 2016 Online Published: June 29, 2016

doi:10.5539/jpl.v9n5p102 URL: http://dx.doi.org/10.5539/jpl.v9n5p102

\begin{abstract}
The enhancement of environmental awareness in both domestic and international level has been accompanied by the growing number of internal authorities and international bodies within which environmentally related disputes can be addressed. Over the years, environmental issues have been discussed by different international judicial courts and arbitration tribunals. Their contribution to enhance the legitimacy of international concerns to the protection of environment is a significant one. They have acted to clarify the international environmental rules within the international legal order and have augmented the ability of domestic legal systems to deal with associated problems more effectively. The international judicial bodies as well as arbitration tribunals have been faced with a rather vague set of rules and principles that made it an enormous task to apply the law to the particular facts of a case in question. Issues relating to the existence, contents and meaning of the certain related concepts took considerable spaces in the contributions of international courts and tribunals in the course of developing international environmental law, particularly the concepts of environmental damage and the liable party to make reparation. International judicial bodies mostly relied on procedural obligations of states and arbitration tribunals on damage itself and the necessity to compensate them. While the damage is mostly confined to significant damage of value-use aspects of the environment, and liable party is focused on the damage causing activities of the operator, the reparation modes are unsteady between only financial compensation and, if possible, near to restitution.
\end{abstract}

Keywords: trans-frontier environmental damage, responsibility, liability, reparation, compensation, restitution, arbitration, adjudication

\section{Introduction}

Despite the environmental protection afforded by several important legal instruments, (Bodansky, 2011) and related developed "soft law" (Sands, 2012, 103), the damage inflicting to environment of both states and global commons and its degradation on a daily basis is a prevailed reality. This is a well-established principle of the international law, and even as a general legal concept that a violation of an international obligation entails responsibility and the necessity of compensation for damages. (Chorzow Factory case, 1928) International instruments for the protection of the environment, which are considered the founders of the principle that State liable for environmental damage, in fact contained an obligation of States that their actions do not cause harm to the territory of the other States. (Stockholm Declaration, Principle 21) Other obligations as to precautionary and prevention principles whose breach could engage the responsibility of States may be found in several instruments of international law and in the customary law as well. The precautionary principle is that in situations where there is a reason believe that something is causing injury to or potentially irreparable to the environment, preventive measures should be taken immediately and the principle of preventive measures requires that actions be taken to prevent known or quantifiable risks, contrary to the precautionary principle, which requires that action is taken to prevent the possibility of creating risks that have not yet been accurately assessed. (Sands, 2012) Preventative measures are generally justified by the fact that they are cheaper, safer and more desirable to prevent damages to the environment, rather than try to repair it later (if, of course, possible to do so). The application of this principle found its origin in due diligence obligation of the State on its territory. (Pulp Mills Case, 2010) 
These obligations accompanied by development of procedural obligations through the jurisprudence of international bodies have greatly enhanced international protection of the environment. It has, inter alia, enabled States that may be affected in the future by environmentally degrading activities of other States to take part in the decision-making process at the vital stage where such potentially harmful activities are embarked upon. This new law of international responsibility attempts to strike a careful balance between international environmental protection and the principle of territorial sovereignty. (Mendis, 2006)

In the event of damage occurrence, some conditions to raise State responsibility about the damages against environment must be met including considerations about the qualifications of the damage itself that must be foreseeable, trans-frontier and serious, substantial or significant. Commentary of the ILC on its draft articles, 2001 notes that: It is to be understood that "significant" is something more than "detectable" but need not be at the level of "serious" or "substantial". The harm must lead to a real detrimental effect on matters such as, for example, human health, industry, property, environment or agriculture in other States. Such detrimental effects must be susceptible of being measured by factual and objective standards. The damage that the States must prevent includes not only the damage on the territory of other States, but also damage in areas beyond the limits of its jurisdiction.(Gabcikovo-Nagymaros Project, 1997) Environmental damage is also a violation of everyone's right to an ecologically balanced environment, which is a fundamental human right. (Bowman and Boyle, 2002)

Indeed, there is no actual interpretation in case law about the notion of ecological damage and the established rules of State responsibility thereof. Environmental treaties do not, generally, regulate possible disputes that can well be solved and to establish accountability of the author and therefore to repair the damages. In fact, the international environmental law suffers from the lack of a structure capable of achieving results, as an International Environmental Court specializing in environmental affairs, could do so. Lacking general regime of international responsibility for causing damage to environment, some cases may be used to illustrate the obstacles to effective redress for ecological damage and find answers to the relating issues as: What entails environmental damages? Is that implies the need to prove fault or it is sine delicto liability? What type of reparation must be available in case of damage to the environment? What is the extent of responsibility and how to assess the damage? This can be done through analyzing the related decisions of the international judicial bodies, in particular International Court of Justice, as well as awards rendered by ad hoc international arbitration tribunals in environmental matters.

\section{International Arbitration Tribunals}

Awards rendered by ad hoc International Arbitration Tribunals have been contributed in development of environmental Law; most of them purely environmental disputes. Arbitration practice, have mostly relied on the rules and principles of customary international law in the field of environmental protection. The following section is devoted to exploring the contribution of arbitration tribunals in development of the both concepts of trans-frontier environmental damage and the issue of international accountability thereto.

\subsection{Trail Smelter Case (United States v. Canada)}

As a result of operation of the smelter in Trail, Canada, near the borders with the United States, owned by the Canadian company, from 1925 onward, some damages caused by the discharge of sulfur dioxide. Damage is felt in Washington State in the territory of the United States. In 1927, the United States government officially took up the case and presented a claim to the government of Canada. After various efforts to settle the case by other means, the two governments submitted the matter to arbitration, signing a compromise to this effect on April 15, 1935. This compromise settled the issue of responsibility. Its first article obligated the Canadian government to pay the United States government $\$ 350,000$ to settle damage claims arising out of smelter activity before January 1, 1932. For periods after this date, the arbitral commission was asked to respond to four questions:

(i) Did the Trail Smelter cause damage after January 1, 1932, and if so, what indemnity should be paid as a consequence?(ii) If the first question is answered affirmatively, should the Trail Smelter be required to refrain from causing damage in the State of Washington in the future, and if so, to what extent?(iii) In light of the preceding question, what measures of regime, if any, should be adopted or maintained by the Trail Smelter?(iv) What indemnity or compensation should be paid on account of the decision of the arbitral tribunal?

In an interim decision, dated April 16, 1938, the arbitral tribunal responded to the first question concerning damage caused by the Trail Smelter since January 1, 1932. For the period between that date and October 1, 1937the tribunal awarded $\$ 78,000$ for damages. The tribunal also decided that the Trail Smelter should be subject to a temporary regime to continue until October 1, 1940, including abstention from causing damage and installation of equipment to control pollution. 
The final decision of the arbitral tribunal, issued March 11, 1941, detailed the facts and topographical, meteorological, and economic conditions of the region subjected to pollution. On the merits, it applied the principle of res judicata, calling it an essential and settled rule of international law and thus refused to review its previous opinion concerning damages before October 1, 1937. It also refused to allow an indemnity to the United States government for damage to crops, trees or other costs during the following period, judging that the government had failed to provide sufficient evidence. The Tribunal noted that it is impossible to determine the amount of damages with absolute certainty. The Tribunal held that there was sufficient evidence in respect of damage caused to property, as well as privately owned lands in Northport, but not in respect of damage caused to livestock, enterprises and the others costs incurred by the State. (Trail Smelter Case, 1938)

Tribunal found that no State has the right to use or permit the use of its territory in such a manner as to cause injury by fumes in or to the territory of another or the properties or persons therein, when the case is of serious consequence and the injury is established by clear and convincing evidence. The Tribunal held that the circumstances of the case shows that the "dominion of Canada is responsible under international law to operate the smelter." (Trail Smelter Case, 1938)

Tribunal implicitly suggests that the obligation to prevent trans-frontier damage is not absolute or sine delicto nature due to the fact that it concerns only damage predictable and which can be prevented. (Goldie, 1995)This reflects the necessary link between Canada and smelter that has led to the actual damage. Canada has not done all it should have done that damage which could have been foreseen and prevented. So, instead of considering whether there are any places impose liability for damages, the Tribunal analyzed the existence and amount of specific forms of damage. (Rosas, 1991) The Tribunal has clearly taken the view that cross-border damage must be serious in order to even activate the State's obligation for compensation.

\subsection{Lake Lanoux Arbitration (France v. Spain)}

The arbitration tribunal in Geneva rendered an award in 1957 in the dispute between France and Spain which arose in connection with the use of Lake Lanoux located on the French territory. The French government in 1917 began to consider the construction of hydroelectric power plants on its territory, which would mean diverting the waters of Lake Lanoux. Spain immediately filed a protest, claiming that the project harmed the interests of the Spanish and insisting to be informed before any steps taken by France in connection with the construction of hydroelectric power plants. February 1949, two countries agreed to establish a Joint Committee composed of engineers to analyze the whole situation and the corresponding report submitted by the two governments. However, the Commission did not succeed and a new special mixed commission formed, in 1955, which is given three months to prepare the report. In 1956 two countries concluded an arbitration compromise.

The Tribunal ruled that the actions of France in connection with the works on the lake without Spain notice, does not constitute a breach of its international obligations provided for in the Treaty of 1866 and supporting Act. Tribunal itself regretted that Spain has not based its claims during the proceedings about the possible pollution of the river Carol, its chemical composition, temperature and other properties that could be considered a violation of Spanish interests.

Contribution of the arbitral award in the case of Lake Lanoux confirm restrictions on the right of coastal States regarding the use of a common river flows, and the importance of cooperation in international law. In these kinds of disputes everything always comes down to finding a balance between competing interests rather than a mere application of rules. The Tribunal pointed out that the interests of both States must be taken into account: "France is authorized to exercise its rights; it can not ignore Spanish interests. Spain is authorized to request that its rights are respected and that its interests are taken into account." (Lake Lanoux Case, 1957)

\subsection{Southern Bluefin Tuna Cases (New Zealand v. Japan; Australia v. Japan)}

In 1982, due to a perceptible decrease on the grounds of excessive fishing, the three countries through a convention began to exert control over fishing of tuna, in that each State set the total allowed catch. Japan is announced that is taken outside fishing boundaries established by prior agreement, justifying its actions by scientific research due to the noticeable recovery of tuna stock. Australia and New Zealand invoked the arbitration provided for in Annex VII to the Convention on the Law of the Sea and initiated proceedings before the International Tribunal for the Law of the Sea, claiming that Japan violated the obligations under Article 64 and Articles 116-119 of the Convention on the Law of the Sea.

The tribunal, recognizing that it is not in a position to assess the scientific evidence, however, noted that the tuna stock diminished all of which require an urgent action in order to preserve the rights of the parties and prevent further deterioration of the tuna stock. The Tribunal referred the parties to the negotiations in order to reach 
agreement on measures to preserve and manage this specific type of tuna. (Bluefin Tuna Case, 1999) Although with serious criticism of Judge Alan Shearer that the Tribunal characterized itself as a diplomatic Agency rather than a judicial body to apply the law, (Separate Opinion of Judge ad hoc Shearer, Bluefin Tuna Case, 1999) it considers itself sufficiently capable to assess the scientific evidence submitted by the State, having decided to impose the obligation of States to refrain from actions that would aggravate the dispute could be implicitly applied a principle of precaution.

Judge Laing argues that the mere fact that the Convention on the Law of the Sea accepted this principle does not mean that it should be given the customary character. (Separate Opinion of Judge Laing, Southern Bluefin Tuna Cases, 1999) Judge Treves considers that there is no need to analyze customary nature of the precautionary principle. It is the logical consequence of the need to not change the factual situation. (Separate Opinion of Judge Treves, Southern Bluefin Tuna Cases, 1999) It follows that the precautionary principle was an integral part of the notion of provisional measures. Although this may be helpful in many situations which challenges the application of the precautionary principle because it makes unnecessary any analysis of its status in general international law, its scope is extremely limited.

\subsection{The MOX Plant Case (Ireland v. United Kingdom)}

The dispute arose between Ireland and the United Kingdom in connection with the construction of the plant in Sellafield on the north-west coast of England. In October 2001, Ireland has requested formation of the arbitral tribunal in accordance with Annex VII of the Convention on the Law of the Sea of 1982 arguing that the United Kingdom violated obligations under the Convention in commissioning of the MOX plant. Ireland asserted the obligations to cooperate in order to take measures to protect the Irish Sea (Articles 123 and 197 of the Convention), the obligation to carry out prior assessment of the impact that the work of the factory could have on the environment (Article 206 of the Convention) and the obligation to protect the marine environment of the Irish Sea, including taking all necessary measures to prevent, reduce or control further radioactive pollution (Articles 192, 193, 194 ,207, 211, 212 and 213 of the Convention).

A year later, Ireland has asked the International Tribunal for the Law of the Sea to impose a temporary measure until the arbitral tribunal established and resolves the dispute. United Kingdom opposed the demands of Ireland stating that Ireland has failed to prove that the actions of the United Kingdom jeopardize the rights of Ireland and caused serious damage, and there is no need for interim measures to establish an arbitration tribunal. Tribunal took the view that interim measures are urgent demands, Ireland request doesn't so, by taking into account the short time that should be elapsed until the establishment of the arbitration tribunal. (MOX Plant Case, 2001)

Rather than imposing provisional measures, the International Tribunal for the Law of the Sea is headed by cooperation in sharing information regarding the risks and effects of the factory as well as ways in which, these risks should be treated. (MOX Plant Case, 2001) In this regard, the Tribunal imposed a clear obligation on both Ireland and the United Kingdom to cooperate and enter into consultations in order to exchange information in connection with the possible consequences of the factory in the Irish Sea, monitor the risks of its work and determine, if necessary, appropriate measures to prevent marine pollution. (MOX Plant Case, 2001) The Tribunal referred to the obligation of cooperation as a fundamental principle of the prevention of the pollution of the marine environment pursuant to Part XII of the Convention on the Law of the Sea and general international law. (MOX Plant Case, 2001)

Despite the absence of scientific certainty regarding the impact of the work of the factory on marine Environment, as well as the extremely hazardous nature of the radioactive material to be used in the factory, Tribunal completely ignored the precautionary principle, (Separate Opinion of Judge Wolfrum, MOX Plant Case, 2001) although some judges felt the need to tackle the issue of possible application of the precautionary principle. (McDorman, 2001)

The Tribunal insisted on the criterion of "serious damage" and in this regard concludes that Ireland has failed to prove that such damage was caused. (MOX Plant Case, 2001) The arbitral tribunal in the MOX Plant dispute takes standard of serious damage as a precondition for application of the precautionary principle. The criterion of serious or irreversible damage actually is an appropriate counterweight to the absence of full scientific certainty when it comes to the consequences of certain actions.

\subsection{Proceedings Pursuant to the OSPAR Convention (Ireland v. United Kingdom)}

Ireland claimed violation of the Article 9 of the Convention for the Protection of the Marine Environment of North-East Atlantic. The Convention regulated the access to information. Ireland claimed that the United Kingdom violated the provision of Article 9 of the OSPAR Convention by not providing the requested reports. 
The United Kingdom has however argued that Article 9 of the Convention does not establish a direct right to obtain information, but rather requires States parties to establish a proper mechanism in domestic law, which United Kingdom complied with by establishing an appropriate mechanism in domestic law.

The Tribunal notes that the State can be held liable in the event that the mechanism established by the internal law proves to be inadequate or competent authority fails to act in a way that is envisaged by an international obligation of the State. To interpret the meaning of "shall ensure" the Tribunal was guided by the objectives of the Convention itself including the obligation to protect the marine and other environments and the obligation to prevent pollution. Drafters of the Convention are carefully introduced a distinction between several levels of commitments. The obligation to "care" "shall ensure" is among looser formulations that leave plenty of room for avoiding certain qualification procedures as unlawful. (OSPAR Convention Case, 2003) However, the question remains that whether it is realistic to expect that this extensive interpretation of the obligations of care can be extended to the other obligations with a similar formulation in the international law of environmental protection.

\subsection{Island of Palmas Case (United States v. The Netherlands)}

The dispute between the Netherlands and the United States was about sovereignty over the Palmas Island. An agreement relating to the arbitration of differences respecting sovereignty over the Island of Palmas (or Miangas) was signed by the United States of America and the Netherlands on January 23, 1925. According to the tribunal, sovereignty not only seen as the exclusive right to carry out activities within the State, but also as the obligation to protect (...) the rights of other States, in particular their right to integrity. (Island of Palmas Case, 1928) Arbitrator Huber believes that "territorial sovereignty cannot limit itself to its negative side, i.e. to excluding the activities of other States; for it serves to divide between nations the space upon which human activities are employed, in order to assure them at all points the minimum of protection of which international law is the guardian." (Island of Palmas Case, 1928)

\subsection{The Dispute in Connection with the Gut Dam (United States v. Canada)}

In 1874 the Canada proposed building a dam on the River St. Lawrence between Adam and Gallops islands. After obtaining approval by the United States, Canada has built a dam. However, the dam was too low to achieve the intended effect, and in 1904 applied for an approval from the US Government to raise the height of what the US government did. In 1951 and 1952, Lake Ontario and River St Lawrence reached the unprecedented high water levels. The level of water in combination with storms and other natural phenomena has caused heavy flooding and damage to the northern and southern shores of the Great Lakes, including Lake Ontario. Beginning in October 1952, several owners of American citizenship initiated proceedings against Canada before the US district court. The note of 10 November 1952 addressed to the US Secretary of State by the Canadian Ambassador it was pointed out that Canada generally recognizes its responsibility to pay compensation for damage incurred by US nationals, provided that those damages can be attributed to the construction and operation of the dam.

International Joint Commission of Lake Ontario was established in 1958. The commission concluded that the water level of Lake Ontario was raised only four inches by the operation of the dam, rather than seven to twelve inches as caused the alleged damages, and that the damage caused by several factors, both natural as well as artificial. The United States and Canada have agreed to establish an international tribunal that would address the requirements for compensation. The decision of the Tribunal about claims for damages had to give answers to a few questions. Who should be compensated for damages by construction and operation of dams against private property? What are the criteria for Canada's obligation to provide compensation for damage provided that it can be attributed to it, and the consequences of its refusal to recognize that the dams cause material damage? What is the amount of damage?

Unfortunately, none of these issues received any response. Canada and the United States reached a settlement by the amount of 350,000 US dollars, outside of the tribunal. (Gut Dam Case, 1968)

\section{International Judicial Practice}

The international judicial bodies have been faced with a rather vague set of rules and principles that made it an enormous task to apply the law to the particular facts of a case in question. Although the main questions in these cases are essentially beyond the environmental context but the resolution of the dispute and the answers to the legal questions, depends on a certain considerations that are directly related to environmental protection. As jurisprudence of two main judicial bodies, permanent court of international justice and international court of justice proves issues relating to the existence, contents and meaning of the certain related concepts particularly, environmental damage and the liable party to make reparation depends on the existing and contents of their 
primary obligations. This leads the judicial bodies to mostly rely on procedural obligations of the states.

\subsection{Corfu Channel Case (United Kingdom v. Albania)}

The International Court of Justice in 1949 resolved a dispute between the United Kingdom and Albania in connection with the collision of British ships with mines in Albanian territorial waters. (Corfu Channel Case, 1949) Albania was found "responsible under international law for the explosions of British ships with marine mines, which occurred on 22 October 1946, in Albanian waters, and for the damage and loss of human life which ensued." (Corfu Channel Case, 1949) This is a rare case in which the Court came to the clear conclusion about the responsibility of the parties to the dispute for the violation of its international obligations and it did most so through the confirming the principle of due diligence in international law. The principle of due diligence as a well-established alternative to still insufficient accepted rules of State responsibility for acts that are not prohibited in international law, now is being considered as a solid principle in protecting environment. It is still an ongoing debate about whether the responsibility of Albania by their nature, were objective or subjective or it is about the responsibility for the illegal act as there is an obligation of the State that its territory is not used for acts that are contrary to the rights of other States. (Barnidge, 2006) Two questions arise in this regard:

First, are those acts contrary to the rights of other States in the sphere of environmental protection? For the purpose of establishing liability on this basis and in the context of environmental damage, significant trans-frontier damage should itself to be contrary to the rights of other States. It is understood that not every trans-frontier damage lead to the responsibility of the State, but only those which are significant and in some ways may correlated with the State.

Second, the dictum of the court explained that Albanian authorities have not tried to prevent the whole event. Mines were placed in period in which the Albanian authorities have control over the channel. Although the general warning of all States on the eve of the moment of the explosion was difficult, if not impossible, it certainly would not prevent Albanian authorities to take, as it is supposed to do, all the necessary measures to immediately warn ships near the danger zone, namely those who are approaching that zone. (Corfu Channel Case, 1949) The significance of the judgment in a dispute in connection with the Corfu Channel in the filed of environmental damage is noticeable and is based on related nature of the relationship between the number of commitments that aim to prevent a damage to environment and obligations of the territorial country not to undertake acts that are contrary to the rights of other countries.

\subsection{United States Diplomatic and Consular Staff in Tehran Case (United States of America v. Iran)}

In a dispute between the United States and Iran over US diplomatic and consular staff in Tehran, International Court of Justice noted the fact that as Iran has not taken any measure in connection with holding American citizens in hostages, is a violation of its international obligations specifically in accordance to the following circumstances:

i) The Iranian authorities were fully aware of their obligations in accordance with international conventions in force to protect the State and representative staff, as well as to take care of their safety; ii) They were fully aware of the urgent need to take appropriate measures; iii) They have the funds available to carry out these obligations, and iv) They have completely failed to act accordingly. (Diplomatic and Consular Staff Case, 1980)

Contributions of above judgment in environmental protection is reflected in clarifying the obligations of prevention as an obligation of due care since the Court devoted more space to concrete steps that countries can take in order to comply with this kind of commitments. The responsibility for violation of the obligation to prevent and, in general, obligations due diligence, on a less strict manner, is so that States are required to use their "best efforts so as, in the absence of such efforts, commitments of due diligence will be violated, and State responsibility will arise." (Dupuy, 1999)

\subsection{Certain Activities carried out by Nicaragua in the Border Area (Costa Rica v. Nicaragua)\&Construction of a} Road in Costa Rica along the San Juan River (Nicaragua v. Costa Rica)

On 18 November 2010, the Government of Costa Rica filed in the Registry of the Court an Application instituting proceedings against the Government of Nicaragua for the incursion into, occupation of and use by Nicaragua's army of Costa Rican territory, as well as for serious damage inflicted to its protected rainforests and wetlands, damage intended to the Colorado River and the dredging and canalization activities being carried out by Nicaragua on the San Juan River. According to Costa Rica, these activities were connected to the construction of a canal across Costa Rican territory from the San Juan River to Laguna los Portillos. Having filed its Application, Costa Rica, on the same day, also submitted a Request for the indication of provisional measures. (Border Area Case, 2010) 
By an Application filed with the Registry of the Court on 22 December 2011, the Republic of Nicaragua instituted proceedings against the Republic of Costa Rica for violations of Nicaraguan sovereignty and major environmental damages on its territory, contending, in particular, that Costa Rica was undertaking construction works near the border area between the two countries along the San Juan River, namely the construction of a road. Further, Nicaragua, in its Application, claimed that the new road caused ongoing damage to the river, on a large scale, by the impetus it inevitably gives to agricultural and industrial activities. Nicaragua invokes a violation of its territorial integrity, the obligation not to cause damage to its territory as well as violations of obligations under international agreements aimed at protecting environment such as the Ramsar Convention and the Convention on Biological Diversity. (Construction of a road in Costa Rica Case, 2011)

The court decided to joint the two cases of Certain Activities carried out by Nicaragua in the Border Area (Costa Rica v. Nicaragua) and Construction of a Road in Costa Rica along the San Juan River (Nicaragua v. Costa Rica) by the Order of 17 April 2013 as the cases involved the same Parties and relate to the area where the common border between them runs along the right bank of the San Juan River and both cases are based on facts relating to works being carried out in, along, or in close proximity to the San Juan River both sets of proceedings are about the effect of the aforementioned works on the local environment and on the free navigation on, and access to, the San Juan River. (Construction of a road in Costa Rica Case, Joinder of proceedings, 2013)

On 16 December 2015, Court finds that, Nicaragua has the obligation to compensate Costa Rica for material damages caused by Nicaragua's unlawful activities on Costa Rican territory and that Costa Rica has violated its obligation under general international law by failing to carry out an environmental impact assessment concerning the construction of Route 1856. (Case Concerning Certain Activities carried out by Nicaragua in the Border Area, 2015)

3.4 Case Relating to the Territorial Jurisdiction of the International Commission of the River Oder (Germany, Denmark, France, Great Britain, Sweden, Czechoslovakia v. Poland)

The dispute of river Oder in Permanent Court of International Justice was concerned to the jurisdiction of the International Commission for Oder, which was established in executing Part XIII of the Treaty of Versailles from 1919, governing the use of the river. Article 343 of the treaty assigns the authority for commission to designate parts of the Oder and its tributaries. In connection with this authorization, the dispute arose between Czechoslovakia, Denmark, France, Germany, Great Britain and Sweden on one side and Poland on the other side due to a difference in interpretation of the content of powers and the manner in which it will be executed. The Court is being asked to reply to the following questions: Does the jurisdiction of the International Commission of the Oder extend, under the provisions of the Treaty of Versailles, to the sections of the tributaries of the Oder, Warthe (Warta) and Netze (Noteć) which are situated in Polish territory, and, if so, what is the principle laid down which must be adopted for the purpose of determining the upstream limits of the Commission's jurisdiction? (River Oder Case, 1929) The Court's judgment laid down the principle that the interests of the community will become a managerial principle in later construction rules about the use of international watercourses, and therefore protection of river environment from pollution. (River Oder Case, 1929)

\subsection{The Case Relating to the Diversion of the Water From the Meuse (Netherlands v. Belgium)}

On May 12th, 1863, Belgium and the Netherlands concluded a Treaty the purpose of which was to settle permanently and definitively the regime governing diversions of water from the Meuse for the feeding of navigation canals and irrigation channels. (River Meuse Case, 1937) Article I of this Treaty provided for the construction below Maestricht, in Netherlands territory, of a new intake which would constitute the feeding conduit for all canals situated below that town and for irrigation in the Campine and in the Netherlands. (River Meuse Case, 1937) When the economic development of the Belgian and Netherlands provinces of Limburg necessitated the enlargement of certain canals and the construction of new works, Netherlands initiated proceedings in the Court by means of a unilateral application, based on the declarations made by both the Netherlands and Belgium in which they accepted the compulsory jurisdiction of the Court under Article 36 (a) of the Statute.

However, the contribution of this case lies in the way in which the Court approached the issue of responsibility, i.e. the careful analysis of any alleged violations of international agreements in force, particularly about the effects of the activities entirely in the territory of a State which has a potential for violation of international obligations vis-à-vis neighboring States. (River Meuse Case, 1937)

Court noted that nothing prevents either Belgium or the Netherlands from making such use as they may see fit of the canals covered by the Treaty, when the canals do not leave their own territory. Each of the two States is at liberty in its own territory to modify such canals, to enlarge them, to transform them, to fill them in and even to 
increase the volume of water in them, provided that the diversion of water at the feeder mentioned in the Treaty and the volume of water to be discharged there from is not affected. (River Meuse Case, 1937)

\subsection{Fisheries Jurisdiction Case (United Kingdom of Great Britain and Northern Ireland v. Iceland)}

Although dealing with the issue of conservation of fisheries resources was heavily criticized, (Declaration of Judge Ignacio-Pinto, Fisheries Jurisdiction Case, 1974) the United Kingdom has requested the Court to comment on several questions, inter alia, on the obligations of the two countries to jointly explore and the need to impose restrictions on fishing to conserve resources. This should take into account that the present dispute is about the preferential rights of Iceland as a coastal State, which depends on fishing, and the rights of the United Kingdom and other States concerned.

The Court expressly stated that both countries have an obligation to take into account the mutual rights and any measures for the conservation of fishery resources. That obligation is, in the opinion of the Court, resulting from the evolution of international maritime law and intensification of fishing which previously applied laissez faire approach replaced with the recognition of the obligation to take into account the rights of other countries and the need to preserve the benefits of all. (Fisheries Jurisdiction Case, 1974)

Applying the principle to the facts of the dispute between The United Kingdom and Iceland leads to asserting obligations of both States to keep constant supervision on fishery resources, to examine together, by scientific information, measures necessary for the conservation, development, and equitable exploitation of these resources. International Court of Justice, confirmed that the same problems must be solved through mutual methods and negotiations considered to be as the most appropriate method for the solution of the dispute. (Fisheries Jurisdiction Case, 1974)

In the present dispute, the Court noted that detailed scientific information and the use of expert opinion will facilitate its position in disputes relating to protection of the environment.

\subsection{Fisheries Jurisdiction Case (Federal Republic of Germany v. Iceland)}

Germany requested the court to determine that the acts committed against German ships carried out by Iceland Coast Guards' ships violates international law and that the Iceland is obliged to indemnify it. (Fisheries Jurisdiction Case, 1973)

The Court held that the documents placed before it not indicating in each case on the concrete form of damage and accompanying amount of compensation that is sought .Moreover, Germany is criticized for not providing proof of these amounts. The Court explicitly stated that the Court may act only in relation to the specific request regarding the existence and amount of each part of the damage about the issue of redress. (Fisheries Jurisdiction Case, 1974)

\subsection{The dispute in relation to Nuclear Tests (New Zealand v. France; Australia v. France)}

Between 1966 and 1972, the French government carried out a series of atmospheric nuclear tests in the territory of French Polynesia in the South Pacific. New Zealand claimed that the tests resulted in the introduction of radioactive substances on its territory. New Zealand has requested the Court to determine that the further atmospheric nuclear testing was contrary to international law and that France should not execute such tests. On the same day, Australia instituted proceedings against France before the International Court of Justice also with regard to nuclear testing in the atmosphere above the South Pacific. In its lawsuit, New Zealand requested the Court to find that the French nuclear tests represent violation of the rights of New Zealand under international law, and these rights will be violated by further tests. As one in a series of arguments, New Zealand said that the nuclear testing is in violation of the law of all members of the international community, including New Zealand, the preservation of unjustified radioactive contamination of soil, marine environment and atmosphere, and particularly the environment of the region in which the tests have been conducted. (Nuclear Tests Case, 1974)

The opportunity that the International Court of Justice had to comment on the very important issues concerning to environmental protection, in particular about causal link between the radiological activities and impairment of environment had been lost after the Court declared that the dispute does not exist after the Statements of French officials that they would no longer run any further tests. Although the complaint from the Court required establishing that the nuclear tests in the atmosphere is contrary to international law, the basic concern of New Zealand was the prohibition of further testing. The Court reached his conclusion based on the fact that New Zealand did not seek compensation for damages and that the request represented only the argument for an order prohibiting the further test and not a separate request whose outcome was declaratory judgment. (Nuclear Tests Case, 1974) 


\subsection{Request for an Examination of the Situation in Accordance with Paragraph 63 of the Court's Judgment of 20 December 1974 in the Nuclear Tests (New Zealand v. France) Case}

In the period between 1974 and 1992, France has carried out a number of underground nuclear tests in the South Pacific. New Zealand has submitted an application to the Court to examine the situation in accordance with paragraph 63of judgments in 1974, claiming that performing underground nuclear tests violate the rights of New Zealand that it possesses under international law, is associated with the view that the execution of a test constitutes an unlawful act. (Request for an Examination of the Situation Case, 1995)

During the proceeding, New Zealand submitted evidence showing that the underground nuclear tests already caused certain problems of pollution and that there is a risk that the further tests will lead to even more serious contamination. Given the failure of France to conduct an assessment of environmental impacts before performing Nuclear Test is even qualify as a violation of customary international law and Convention on the protection of natural resources and environment of the region of the southern Pacific since 1986, of which France is a Contracting party. (Request for an Examination of the Situation Case, 1995)

International Court of Justice took the view that it's judgment of 1974 concerned only nuclear tests in the atmosphere and that it can not be considered the issue of underground nuclear testing. (Request for an Examination of the Situation Case, 1995)

Regardless of the obligation of States to respect and protect the environment (Request for an Examination of the Situation Case, 1995) the existence of a growing corpus of rules of international law regarding environmental protection, has confirmed. (Stephens, 2009, 148) Allegations of New Zealand that the principle number 21 and Stockholm Principle 2 of the Rio Declaration are solidly grounded in customary international law, (Request for an Examination of the Situation, 1995) found supports in the opinions of individual judges of the ICJ.

Judge Weeramantry is provided a serious and detailed analysis of individual principles of international law, environmental protection, in particular the precautionary principle, the principle of evaluation of environmental impacts and unlawful introduction of nuclear material into sea. Referring to the arbitration award in the Trail Smelter case and the principle 21 of Stockholm Declaration, the judge Weeramantry notes that: No nation has the right to conduct activities that cause damage to the environment of any other nation. Moreover, in his view, principle 21 is deeply rooted in the common sense, jurisprudence, international Conventions and customary international law. (Dissenting opinion of Judge Weeramantry, Legality of the Threat or Use of Nuclear Weapons Case, 1996a)

A similar understanding of the Judge Koroma for whom international environmental law has reached such a level of development that according to contemporary international law, there is probably a duty not to cause substantial or serious damage, and not to discharge of hazardous substances. (Dissenting opinion of Judge Koroma, Nuclear Tests Case, 1995) In the opinion of ad hoc Judge Palmer, there is a commitment of notifying other countries where the State undertakes activities that could cause damage to the environment of other States. (Dissenting opinion of Judge ad hoc Palmer, Nuclear Tests Case, 1995)

In addition, opinions of certain number of judges dealing with the environmental case were not by contesting their applicability but, on the contrary, by emphasizing their importance to the current level of development of international law.This especially applies to the comprehensive nature of the principle that the State has obligation to ensure that activities undertaken in their territory does not cause damage to other countries. This principle should include situations in which the amount and cause of cross-border damage are unclear and would take into account the contribution of the precautionary principle, but also the situation regarding damage to the environment of space beyond national jurisdiction of States, the so-called global commons.

\subsection{Legality of the Threat or Use of Nuclear Weapons Case}

In 1994, General Assembly of the United Nations asked the International Court of Justice to give an advisory opinion regarding the legality of the threat or use of nuclear weapons. International Court of Justice has taken the opportunity to comment on the concept of environment, recognizing that the environment is under daily threat and that the use of nuclear weapons constitutes a catastrophe for the environment that is not an abstract but a living space, quality of life and health of human beings including future generations. More importantly, the Court explicitly stated that the existence of a general obligation of States to ensure that the activities undertaken within their jurisdiction and control, respect the environment of other States and areas beyond national jurisdiction or control is now a part of the body of international law concerning the environment.

Although the Court does not consider decisive whether the agreements with the objective of the environmental protection can be applied in time of armed conflict, on the obligation not to cause damage to the environment 
sees no obligations that the purpose had absolute abstention from the use of such weapons during the Armed conflicts, and the protection of the environment is seen as one of the elements by which it can assess whether the actions were consistent with the principles of necessity and proportionality. (Legality of the Threat or Use of Nuclear Weapons Case, 1996, 27-30)

The Court was criticized by a number of judges. Judge Guillaume notes that the imperfections of advisory opinion on the right policies considering environmental law and that the Court too lightly and superficially passed over these matters. (Separate Opinion of Judge Guillaume, Legality of the Threat or Use of Nuclear Weapons Case, 1996) Judge Ranjeva asked about the priority that "ecological order "should have over the" nuclear order". (Separate Opinion of Judge Ranjeva, Legality of the Threat or Use of Nuclear Weapons Case, 1996) Judge Weeramantry's very concrete opinion that the use of nuclear weapons under any circumstances is contrary to international law was the sole attitude presented in the case for absolute prohibition of such weapons. Judge Weeramantry supports his assertion mostly on the rules of environmental protection, insisting on using of nuclear weapons would cause damage against environment and ecosystems, the damage for future generations, classic cross-border damage, and damage to the food supply. (Dissenting opinion of Judge Weeramantry, Legality of the Threat or Use of Nuclear Weapons Case, 1996a)

In terms of environmental protection, Judge Koroma has criticized the approach of the advisory opinion from which it follows that the greatest significance of the Court devoted to the fact that the right to self-defense should not be deprived countries on the basis of the rules of international treaty law which aims at environmental Protection. Judge Koroma considered that the matter should be treated differently and considerations of the consequences for natural environment such as denial of drinking water for humankind and other resources needed for its life. (Dissenting opinion of Judge Koroma, Legality of the Threat or Use of Nuclear Weapons, 1996)

Although from the point of recognition of the rules of international environmental law the advisory opinion has a significance contribution in affirmation of such rules, when it comes to the application of the rules on liability for environmental damage its contribution is only indirect and is reflected in the confirmation of the State's obligations to activities undertaken in its territory does not cause damage to the territories of other countries or areas beyond national jurisdictions.

\subsection{Gabčikovo-Nagymaros Project Case (Hungary/Slovakia)}

The dispute arose in connection with the construction of a series of dams on the Danube, a joint project of Hungary and Czechoslovakia, regulated by a bilateral agreement of 16 September 1977. The contract was provided for the construction of two series of dams, one upstream in Gabcikovo in the territory of Czechoslovakia and the other downstream in the territory of Hungary (Nagimaroš). The contract also contained provisions that were related to environmental protection, namely the obligations of States parties to take appropriate measures to ensure the quality of water, nature and interests with regard to fishing (Articles 15, 19 and 20 of the Treaty of 1977). On 13 May 1989 the Hungarian Government adopted a decision to suspend work in Nagimaroš until the end of the different studies in terms of economic and environmental impacts of the project. Czechoslovakia objected to this decision and two countries have started negotiations in order to incorporate any changes in the project. The agreement is not reached. In November 1991, Czechoslovakia has begun construction of the so-called "temporary solution"- the famous $\mathrm{C}$ variants, which consisted in the construction of a new dam on Czechoslovak territory near the town of Čunovo. Hungary qualified $\mathrm{C}$ variant as a violation of the Treaty of 1977 and in the note dated 19 May 1992, informed the government of Czechoslovakia that it no longer considers itself bound by the Agreement since 1977. After the division of Czechoslovakia into the Czech and Slovak Republics, Hungary and Slovakia on 7 April 1993 concluded agreement in which they agreed to refer the dispute to the International Court of Justice. In particular, the Court was asked to comment on three issues:

Whether the Hungary was entitled to suspend and later completely abandon work on Nagimaroš project, whether Czechoslovakia was entitled to proceed in 1991 with temporary decision, the so-called Variant C, and in 1992 put into operation and what are the legal consequences of termination notice of the Agreement of 1977 that the Hungarian government issued on May 1992. (Gabcikovo-Nagymaros Project Case, 1993)

In its judgment of 25 September 1997, the International Court of Justice has held that both act- both suspension and complete abandonment of works by Hungary and commissioning Variants $\mathrm{C}$ by Czechoslovakia-constitute unlawful acts, in accordance with the rules on State responsibility for an unlawful act, create an obligation for both countries to make compensation for the damage caused, unless they agree otherwise.

When considering the first question - validity or unlawfulness of the decision of the Hungarian government to suspend and then completely abandon work in Nagimarošu, the Court had to respond to allegations of Hungary 
that its decision was due to the State of emergency to ensure the preservation of ecological balance, which Hungary actually tried to justify its actions. In this regard, the International Court of Justice has confirmed that the concern of Hungary for the natural environment of the region truly represents the fundamental interests. However, the Court insisted on clearly-established risk at the time as a necessary condition for the existence of the State of emergency. Moreover, the danger had to be immediate and not merely possible. The fact that Hungary on several occasions during 1989 emphasized uncertainties related to the impact that the project could have on the environment, as well as on the difficulties encountered by that of science data, Court found that in a given case it could determine that the risk to the environment was certain and close enough. (Gabcikovo-Nagymaros Project Case, 1993)

The Court did not find sufficient evidence to the conclusion that the Czechoslovakia refused to consult with Hungary about the desirability and necessity of measures to protect environment. (Gabcikovo-Nagymaros Project Case, 1993) Finally, having established the unlawfulness of the acts both by Czechoslovakia and Hungary, the International Court of Justice insisted on compensation which, as far as possible, should eliminate all consequences of unlawful acts. Hungary referred to the application of the rule of restitutio in integrum, requiring the re-establishment of joint control by the two countries over installations and restoring the river flow to the level before the unlawful diversion. Hungarian explicitly sought compensation for damage caused to the fauna, flora, soil, underground and ground water as well as the damage that Hungarian people suffered due to increased uncertainty regarding their future. In addition to damages, the Hungarian Government requested the Court to make a declaration about the other potential consequences of responsibility for an unlawful act Cessation of unlawful acts and providing guarantee that these acts will not be repeated.

Court took the opportunity to draw attention to the importance of "Due diligence and Prevention" in the sphere of environmental protection because of irreplaceable character of environmental damage and limitations inherent in very mechanism of compensation of this kind of damage. Nevertheless, the problem of State responsibility for environmental damage is left to the parties, by saying that for the purposes of the case, parties should work together for a new way of observing impacts of Gabcikovo for the environment. (Gabcikovo-Nagymaros Project Case, 1993)

The Court found that the consequences of illegal acts completely eliminated if the States to dispute continue to cooperate in joint use of the river. When we take into account the fact that both countries committed unlawful acts which were prejudicial against each other, the question could be resolved in a satisfactory manner if the Court found that the State waived mutual claims. (Gabcikovo-Nagymaros Project Case, 1993)

Hungary argued that, the damage resulting from unlawful acts of Slovakia is completely different in nature from the damage it has caused by its own unlawful act against Slovakia. The first one involved, inter alia, the damage only to the environment while in the second one the damage generally entailed economic losses in connection with the operation of the plant. International Court of Justice came to the conclusion that all issues relating to the protection of the environment can be solved with cooperation between State, the Court did not want to engage in possible violation of obligations by the Slovakia to prevent the cross-border damage. Moreover, the court completely avoids identification of concrete facts regarding the amount and extent of environmental damage caused by the project, leaving this issue to be resolved by the parties.

On the contrary to the writers believing the court made a great contribution to the development and promotion of international rules regarding the environmental protection (Stephens, 2009) which, they believe, upheld the ability of the court to solve disputes with ecological nature, the approach adopted by the Court can be considered minimalist especially since repeatedly it gave priority to guarantee the stable legal relations of the norms of international environmental law. In particular, objections mostly related to failure to provide opportunities to explore the principles of prevention and precaution. The Court qualifies sustainable development as a simple "concept" that the judge Weeramantry criticized in his separate opinion, considering that this is far more than that, the principle of the normative content of the essential solution for dispute. (Separate Opinion of Judge Weeramantry, Gabcikovo-Nagymaros Project Case, 1997b)

\subsection{Pulp Mills on the River Uruguay (Argentina v. Uruguay)}

The dispute between Argentina and Uruguay is the first true ecological dispute ever referred to the International Court of Justice. In addition, it is the first dispute in which the Court explicitly requested to comment on specific violation of international obligations and, possibly, to establish international responsibility of State in ecological issues.

The Court has drawn a distinction between obligations with procedural and substantive nature, considering them related in functional terms but also independent in terms of determining their violation. Accordingly, the Court 
found that the Uruguay violated procedural obligations under the Statute of the River Uruguay of 1975 . The Court has in fact held that a simple Statement that Uruguay violated the procedural obligation of notification constitutes sufficient satisfaction for Argentina. Other available consequences of established international responsibility of State did not take into consideration by the court. (Pulp Mills Case, 2010)

While Argentina argued that procedural or substantive character of the obligation has no impact on the consequences of the violations, in the sense that the violation of procedural obligations could entail application of the rules of restitutio in integrum, the rules on reparation or the termination of the repetition or prohibiting the unlawful act, Uruguay has taken the view that the procedural nature of the obligations is of importance in determining the consequences of the injuries, and that, restitution in this case would not constitute as an adequate measure. Statute of 1975 as a "lex specialis" in articles 42 and 43 provides for compensation rather than restitution in the status quo ante as an adequate form of reparation for the pollution of the river. Customary international law provides for restitution the status quo ante as a form of reparation. (Pulp Mills Case, 2010)

In cases where restitution is impossible or creates a burden which is disproportionate to the benefits that arose from it, reparation acquires the form of compensation or satisfaction, and sometimes both of them. (Gabčíkovo-Nagymaros Project Case, 1997; Construction of a Wall Case, 2004; Genocide Convention Case, 2007) Whether in a particular case an appropriate form of reparation constitute restitution, compensation or something else, will depend on the opinion of the Court, as to the nature and extent of the damage, and the nature of the unlawful act. Form of reparation depends on the nature and extent of the damage, which was put forward by the International Court of Justice in Avena case. (Avena Case, 2004) Violation of the obligations with a procedural nature obviously is not the same as violation of material obligations. As the Court has failed to establish that there has been a breach of material obligation to prevent pollution, it comes to the conclusion that there is no place for the approval of a request of Argentina about the compensation for damages allegedly suffered in various economic sectors. (Pulp Mills Case, 2010) Uruguay argues that "Articles 42 and 43 of the Statute provide for compensation rather than restitution as an adequate form of reparation for the pollution of the river Uruguay. (Pulp Mills Case, 2010) Articles 42 and 43, relating to pollution, do not come to their purpose or effect reflected in the exclusion of all forms of reparations except damages for breaches of procedural obligations under the Statute of 1975. (Pulp Mills Case, 2010) The Court finds it unnecessary to declare whether the provisions of Articles 42 and 43 of the Statute of the River Uruguay of 1975 established the obligations of compensation for liability. (Pulp Mills Case, 2010)

\subsection{Aerial Herbicide Spraying (Ecuador v. Colombia)}

In 2008, Ecuador instituted proceedings before the International Court of Justice against Colombia in connection with the alleged aerial spraying by Colombia of toxic herbicides near, at and across its border with Ecuador. Ecuador States that "the spraying has already cause serious damage to people, crops, animals and the natural environment on the Ecuadorian side border, and that poses a serious risk of further damage. (Aerial Herbicide Spraying, 2008) In fact, Ecuador is asking the Court to comment on the whether Colombia has violated obligations under international law by being brought or allow the introduction of toxic herbicides in the territory of Ecuador, which has resulted in harm to the human health, properties and the environment. In addition, Ecuador explicitly requests to Colombia to compensate for any loss or damage which is a consequence of the unlawful act, among other things, Environmental damage and the depletion of natural resources. (Aerial Herbicide Spraying, 2008) In 2013, the court declared that, the case brought by the Republic of Ecuador against the Republic of Colombia on 31 March 2008 was removed from the Court's List on 13 September 2013 at the request of Ecuador because of an Agreement between the Parties dated 9 September 2013. The Agreement establishes, inter alia, an exclusion zone, in which Colombia will not conduct aerial spraying operations, creates a Joint Commission to ensure that spraying operations outside that zone have not caused herbicides to drift into Ecuador and, so long as they have not, provides a mechanism for the gradual reduction in the width of the said zone; according to the letters, the Agreement sets out operational parameters for Colombia's spraying program, records the agreement of the two Governments to ongoing exchanges of information in that regard, and establishes a dispute settlement mechanism. (Aerial Herbicide Spraying, 2013)

\subsection{Whaling in the Antarctic (Australia v. Japan: New Zealand Intervening)}

In 2010, proceedings were initiated against Japan by Australia in relation to whaling on Antarctica. Australia argues that Japan has violated its obligations under international law, in particular obligations under the International Convention on the regulation of whaling, as well as other international obligations concerning the conservation of marine mammals. (Whaling in the Antarctic Case, 2010) In addition to the International Convention on the Regulation of hunting whale, Australia relies on a breach of some other international 
conventions in the sphere of protection of environment, such as the Convention on Biological Diversity and the Convention on International Trade in Endangered Species of flora and fauna.

This will be an opportunity that the International Court of Justice copes with all the obstacles that come with the process establishing a breach of international obligations with ecological character.

Decisions of the International Court of Justice, as well as awards rendered by ad hoc International Arbitration Tribunals have been contributed in development of environmental Law. Other possible authorities to address the international environmental problems, would be the International Tribunal for the Law of the Sea (Boyle, 2007) and Annex VII arbitral tribunals, (Activities in the Area Case, 2011). Dispute Settlement Understanding established under the Agreement of the World Trade Organization, (Tarasofsky, 2005) various international human rights courts (Boer, 2015) and World Bank Inspection Panel. (Gualtieri, 2001) These are all the possible bodies that would constitute international forum for disputes with environmental aspects and each requires an independent study.

\section{Conclusion}

The implementation of the international responsibility of the State in environmental disputes raises many questions, inter alia: What is meant by environmental damage? Does it include damage to use-values or non-use values or both? Under what conditions a State can be held responsible for trans-frontier damage caused to the environment of other state or areas beyond national jurisdictions? What consequences will lead this responsibility in terms of repairing the damage caused? Analyzing possible responses to these questions in international jurisprudence of both judicial and arbitrational bodies signify that the responsibility in question suffers from many shortcomings and weaknesses. There is no comprehensive convention on international responsibility for environmental matters but there are many specific conventions that only cover liability of private parties for compensation of damages. While International judicial bodies relied on procedural obligations of states, arbitration tribunals focused on damage itself and the necessity for compensation. The damage is mostly confined to significant damage of value-use aspects of the environment, and liable party is focused on the damage causing activities of the operator The reparation modes are unsteady between only financial compensation and, if possible, near to restitution. There has been resurgence in state to state arbitration in environmental matters, through which the compromises lead the Tribunals on the questions to be addressed, bypassing the obstacles common to international adjudications. On the other hand, the ICJ, as a prominent international judicial body, faces many procedural and substantial limitations that prevent it from being seen as an appropriate court to resolve environmental disputes by States, although several environmental treaties refer to it as a judicial body of settlement of possible related disputes.

\section{References}

Activities in the Area Case. (2011). Responsibilities and Obligations of States Sponsoring Persons and Entities with Respect to Activities in the Area, ITLOS Case No. 17, (Advisory Opinion) I.L.M., 50, 458.

Aerial Herbicide Spraying Case (2008b). Case concerning Aerial Herbicide Spraying, in Ecuador. Colombia, Case removed from the Court's List at the request of the Republic of Ecuador.

Aerial Herbicide Spraying Case. (2008a). Case concerning Aerial Herbicide Spraying, in Ecuador. Colombia, Application instituting Proceedings, 4-26.

Avena Case. (2004).Avena and Other Mexican Nationals, Mexico v. United States of America, Judgment. ICJ Reports, 59.

Barnidge, R. P. (2006). The Due Diligence Principle under International Law. International Community Law Review, 8(1), 105. http://dx.doi.org/10.1163/187197306779173194

Bodansky, D. (2011). The Art and Craft of International Environmental Law. Harvard University Press, Cambridge, Mass. reprint edn, 175-271.

Boer, B. (2015). Environmental Law Dimensions of Human Rights. Oxford University Press, Oxford, United Kingdom. 135-179. http://dx.doi.org/10.1093/acprof:oso/9780198736141.001.0001

Border Area Case. (2010). Case concerning Certain Activities carried out by Nicaragua in the Border Area, Costa Rica v. Nicaragua, Application instituting proceedings, 3.

Born, G. (2011). International Arbitration: Cases and Materials. Wolters Kluwer: Aspen Casebook Series, Groningen, Netherlands. 
Bowman, M., \& Boyle, A. (2002). Environmental Damage in International and Comparative Law: Problems of Definition and Valuation. Oxford University Press, Oxford, United Kingdom. http://dx.doi.org/10.1093/acprof:oso/9780199255733.001.0001

Boyle, A. (2007). The Environmental Jurisprudence of the International Tribunal for the Law of the Sea. the International Journal of Marine and Coastal Law, 22(3), 369-381. http://dx.doi.org/10.1163/157180807781870354

Case Concerning Certain Activities carried out by Nicaragua in the Border Area. (2015). International Court of Justice, 16 December 2015.

Chorzow Factory Case. (1928). The judgment in the Chorzow Factory case of 13 September 1928. Factory of Chorzów case, PCIJ, 17(Ser.A), 29.

Construction of a Wall Case. (2004). Legal Consequences of the Construction of a Wall in the Occupied Palestinian Territory, Advisory Opinion, ICJ Reports, 198.

Corfu Channel Case. (1949). United Kingdom v. Albania, Judgment, 9 April 1949. ICJ Reports, 22-36.

Diplomatic and Consular Staff Case. (1980). United States Diplomatic and Consular Staff in Tehran, Judgment. ICJ Reports, 68.

Dupuy, P. M. (1999). Reviewing the Difficulties of Codification on Ago's Classification of Obligations of Means and Obligations of Result in Relation to State Responsibility. European Journal of International Law, 10(2), 371-379. http://dx.doi.org/10.1093/ejil/10.2.371

Fisheries Jurisdiction Case. (1974a). Fisheries Jurisdiction Case, Federal Republic of Germany v. Iceland, Merits, Judgment. ICJ Reports, 204-205.

Fisheries Jurisdiction Case. (1974b). Fisheries Jurisdiction Case, United Kingdom v. Iceland, Merits, Judgment. ICJ Reports, 21-32.

Gabcikovo-Nagymaros Project Case. (1997). Hungary. Slovakia, Judgment. ICJ Report, 41-81.

Genocide Convention Case. (2007). Application of the Convention on the Prevention and Punishment of the Crime of Genocide, Bosnia and Herzegovina v. Serbia and Montenegro, Judgment. ICJ Reports, 233.

Goldie, L. F. E. (1965). Liability for Damage and the Progressive Development of International Law. International Comparative Law Quarterly, 14, 1226-1231. http://dx.doi.org/10.1093/iclqaj/14.4.1189

Gualtieri, G. A. (2001). The Environmental Accountability of the World Bank to Non-State Actors: Insights from the Inspection Panel. the British Year Book of International Law, 71, 213-253.

Guillaume, G. (1996). Separate Opinion of Judge Guillaume, Legality of the Threat or Use of Nuclear Weapons Case, Advisory Opinion. ICJ Reports, 287.

Gut Dam Case. (1968). Gut Dam Case, Canada v. United States of America, Lake Ontario Claims Tribunal, Ottawa and Washington. IELR, 1, 418-423.

Ignacio-Pinto, L. (1974). Declaration of Judge Ignacio-Pinto, Fisheries Jurisdiction Case, United Kingdom v. Iceland, Merits, Judgment. ICJ Reports, 35-38.

Island of Palmas Case. (1928). Island of Palmas Case, Netherlands v. United States of America. RIAA, 2, 839.

Koroma, A. G. (1995). Dissenting opinion of Judge Koroma, Nuclear Tests Case, New Zealand v. France. ICJ Reports, 375-578.

Laing, A. (1999). Separate Opinion of Judge Laing, Southern Bluefin Tuna Cases, New Zealand v. Japan, Australia v. Japan International Tribunal for the Law of the Sea, 13.

Lake Lanoux Case. (1957). Lake Lanoux Case, France v. Spain, Arbitral Tribunal, Geneva. IELR, 1. 382-384.

McDorman, T. L. (2001). International Tribunal for the Law of the Sea. Yearbook of International Environmental Law, 12, 596.

Mendis, C. (2006). Sovereignty vs. trans-boundary environmental harm: The evolving International law obligations and the Sethusamuduram Ship Channel Project, (United Nations, Nippon Foundation, Japan), 8.

MOX Plant Case. (2003). The MOX Plant Case, Ireland v. United Kingdom Arbitral Tribunal. IELR, 5, 530-545.

Nuclear Tests Case. (1974). Nuclear Tests Case, New Zealand v. France, Judgment. ICJ Reports, 475. 
Nuclear Weapons Advisory Opinion Case. (1996). Legality of the Threat or Use of Nuclear Weapons, Advisory Opinion. ICJ Reports, 240-243.

OSPAR Convention Case. (2003). Dispute Concerning Access to Information Under Article 9 of the OSPAR Convention, Ireland v. United Kingdom Arbitral Tribunal, The Hague, 2 July 2003. IELR, 5, 127-138.

Palmer, G. (1995). Dissenting opinion of Judge ad hoc Palmer, Nuclear Tests Case, New Zealand v. France. ICJ Reports, 408.

Pulp Mills Case. (2010). Case concerning Pulp Mills on the River Uruguay, Argentina v. Uruguay, Judgment of 20 April 2010, ICJ Reports, 77-78.

Ranjeva, R. (1996). Separate Opinion of Judge Ranjeva, Legality of the Threat or Use of Nuclear Weapons Case, Advisory Opinion. ICJ Reports, 296.

Request for an Examination of the Situation Case. (1995). Request for an Examination of the Situation in Accordance with Paragraph 63 of the Court's Judgment of 20 December 1974 in the Nuclear Tests Case, New Zealand v. France. ICJ Reports, 10-48.

River Meuse Case. (1937). Diversion of Water from the River Meuse in the Netherlands. Belgium, Judgment of 28 June $1937, P C I J, 70$ (Ser. A-B), 6-35

River Oder Case. (1929). Territorial Jurisdiction of the International Commission of the River Oder, Judgment, PCIJ, 23 (Ser. A), 6-28.

Rosas, A. (1991). Issues of State Liability for Trans-frontier Environmental Damage. Nordic Journal of International Law, 29(60), 30.

San Juan River Case. (2011). Case concerning Construction of a road in Costa Rica along the San Juan River, Nicaragua v. Costa Rica. ICJ Press Release, 40, 15-40.

Sands, P., \& Peel, J. (2012). Principles of international environmental law (3rd ed.). Cambridge University Press, Cambridge, England. 103, 117. http://dx.doi.org/10.1017/CBO9781139019842

Shearer, A. (1999). Separate Opinion of Judge ad hoc Shearer, Southern Bluefin Tuna Cases, New Zealand v. Japan Australia v. Japan International Tribunal for the Law of the Sea.

Southern Bluefin Tuna Cases. (1999). Southern Bluefin Tuna Cases, New Zealand v. Japan, Australia v. Japan International Tribunal for the Law of the Sea, 70-120.

Stephens, T. (2009). International Courts and Environmental Protection. Cambridge University Press, Cambridge, United Kingdom. 148. http://dx.doi.org/10.1017/cbo9780511576034

Tarasofsky, R. (2005). Report on Trade, Environment, and the WTO Dispute Settlement Mechanism, Concerted Action on Trade and Environment, sponsored by the European Commission, 4-10.

Trail Smelter Case. (1938). Trail Smelter Case, Canada v. United States of America, Arbitral Tribunal, Washington, (IELR), 1, 258-310.

Treves, T. (1999). Separate Opinion of Judge Treves, Southern Bluefin Tuna Cases, New Zealand v. Japan, Australia v. Japan International Tribunal for the Law of the Sea, 9.

Weeramantry, C. (1996). Dissenting opinion of Judge Weeramantry, Legality of the Threat or Use of Nuclear Weapons Case, Advisory Opinion. ICJ Reports, 347-469.

Weeramantry, C. (1997). Separate Opinion of Judge Weeramantry, Gabcikovo-Nagymaros Project, in Hungary. Slovakia, Judgment. ICJ Reports.

Whaling in the Antarctic Case. (2010). Case concerning Whaling in the Antarctic, in Australia. Japan Application instituting Proceedings, 4.

Wolfrum, R. (2001). Separate Opinion of Judge Wolfrum, The MOX Plant Case, Ireland v. United Kingdom, International Tribunal for the Law of the Sea.

\section{Copyrights}

Copyright for this article is retained by the author(s), with first publication rights granted to the journal.

This is an open-access article distributed under the terms and conditions of the Creative Commons Attribution license (http://creativecommons.org/licenses/by/3.0/). 